\title{
Two new species of Hoya R.Br. (Apocynaceae, Asclepiadoideae) from Borneo
}

\author{
Michele Rodda' \\ I The Herbarium, Singapore Botanic Gardens, 1 Cluny Road, 259569 Singapore \\ Corresponding author: Michele Rodda (rodda.michele@gmail.com)
}

Academic editor: S. Razafimandimbison | Received 10 April 2015 | Accepted 13 June 2015 | Published 21 July 2015

Citation: Rodda M (2015) Two new species of Hoya R.Br. (Apocynaceae, Asclepiadoideae) from Borneo. PhytoKeys 53: 83-93. doi: 10.3897/phytokeys.53.5079

\begin{abstract}
Two new Hoya R.Br. species from Borneo are described and illustrated. The first, Hoya ruthiae Rodda was collected in Sabah on Bukit Baturong, a limestone outcrop. It is one of the few species in the genus to have clear exudate. It is compared with the morphologically related Hoya uncinata Teijsm. and Binn. The other, Hoya bakoensis Rodda, was collected in the kerangas forests of Bako National Park. It belongs to Hoya section Acanthostemma (Bl.) Kloppenb., a section with numerous members in the Philippines but under-represented in Borneo.
\end{abstract}

\section{Keywords}

Bako National Park, kerangas, limestone flora, Malaysia, Sabah, Sarawak, taxonomy

\section{Introduction}

Hoya R.Br. is a large and complex genus with more than 500 published species names (IPNI 2015). Kleijn and van Donkelaar (2001) estimated that these names might represent 200-300 species. However their estimate was very conservative. Since 2001 more that 200 new Hoya names have been published (IPNI 2015) and the species number estimate for the genus may therefore now lie in between 350 and 450, taking into account a large number of synonyms expected in a horticulturally significant genus. The genus is particularly diverse in the island of Borneo where Nutt (2001) listed 
21 species while more recent research bring up the number to an estimated 60-70 species for Sabah alone (Lamb et al. 2014). In Brunei a preliminary checklist comprises 27 species including three undescribed taxa (Rodda 2014).

Numerous papers have been recently published documenting new Hoya species from Borneo (Green and Kloppenburg 2014; Rodda and Nyhuus 2009; Rodda and Simonsson 2010; 2011a; b; Rodda and Simonsson Juhonewe 2013a; b; Rodda et al. 2011; 2014a; b; Trân et al. 2011). More notably, Lamb et al. (2014) published eight new taxon names in the genus Hoya all described based on materials from Sabah originally collected sterile and brought into cultivation at Kipandi Park (Kampung Kipandi, Moyog, Sabah) where they bloomed and were identified as new taxa. An extensive introduction on the morphology and ecology of Bornean Hoya is also found in Lamb et al. (2014).

Two further new Hoya species from Borneo are here described. The first, collected by Ruth Kiew in Sabah, is also widely available in cultivation, and is here named Hoya ruthiae Rodda. The second was collected by the author in March 2015 during an expedition to Bako National Park (Sarawak, Malaysia) to which it is named after.

\section{Species treatments}

\section{Hoya ruthiae Rodda, sp. nov.}

urn:lsid:ipni.org:names:77148380-1

Figs 1,2

Diagnostic characters. Similar to Hoya uncinata Teijsm. and Binn as both species have clear exudate, deeply lobed rotate corolla and corpusculum of the pollinarium almost as large as the pollinium. The flattened corolla is smaller $(1.5-1.7 \mathrm{~cm}$ in diameter) with ovate lobes in $H$. uncinata, while the corolla of $H$. ruthiae is $1.8-2.2 \mathrm{~cm}$ in diameter with narrowly lanceolate lobes.

Type. Malaysia, Sabah, Lahad Datu, Bukit Baturong, on limestone, 7 July 2000, Kiew R RK5029 (SING, holotype; barcode SING0077484).

Description. Delicate lithophytic climber with clear exudate in all vegetative parts; all vegetative parts glabrous. Leafy stems cylindrical, slender, up to $4 \mathrm{~mm}$ in diameter, dark brown or grey, with membranaceous peeling bark; internodes $5-15 \mathrm{~cm}$ long. Petioles terete, fleshy, 5-15 × 1.5-3 mm in diameter, lamina lanceolate, fleshy, (5-)7-15 × $1.5-3 \mathrm{~cm}$, apex acute-acuminate, base cuneate, light green above turning red in bright light with numerous grey spots, lighter green underneath; penninerved, secondary veins obscure. Inflorescences pseudo-umbelliform or globular, 3-4 cm in diameter, 4-20 flowered; peduncles persistent, extra-axillary, terete, $1-3 \mathrm{~cm} \times 1.5-2.5 \mathrm{~mm}$ in diameter, glabrous; pedicels $10-15 \mathrm{~mm} \times 0.5-0.8 \mathrm{~mm}$ in diameter, glabrous. Buds conical with a 5-ridged base, ca. $10 \times 6 \mathrm{~mm}$. Calyx lobes triangular, white-pink 1.3-1.5 $\times 0.7-1 \mathrm{~mm}$, apex rounded, glabrous; basal colleters 1 in each sepal sinus, ovoid. Corolla rotate, deeply lobed, $1-1.5 \mathrm{~cm}$ in diameter, $1.8-2.2 \mathrm{~cm}$ when flattened, white tinged pink, thinly and minutely pubescent inside, outside glabrous, tube $1.5-2 \mathrm{~mm}$ long; corolla lobes narrowly 


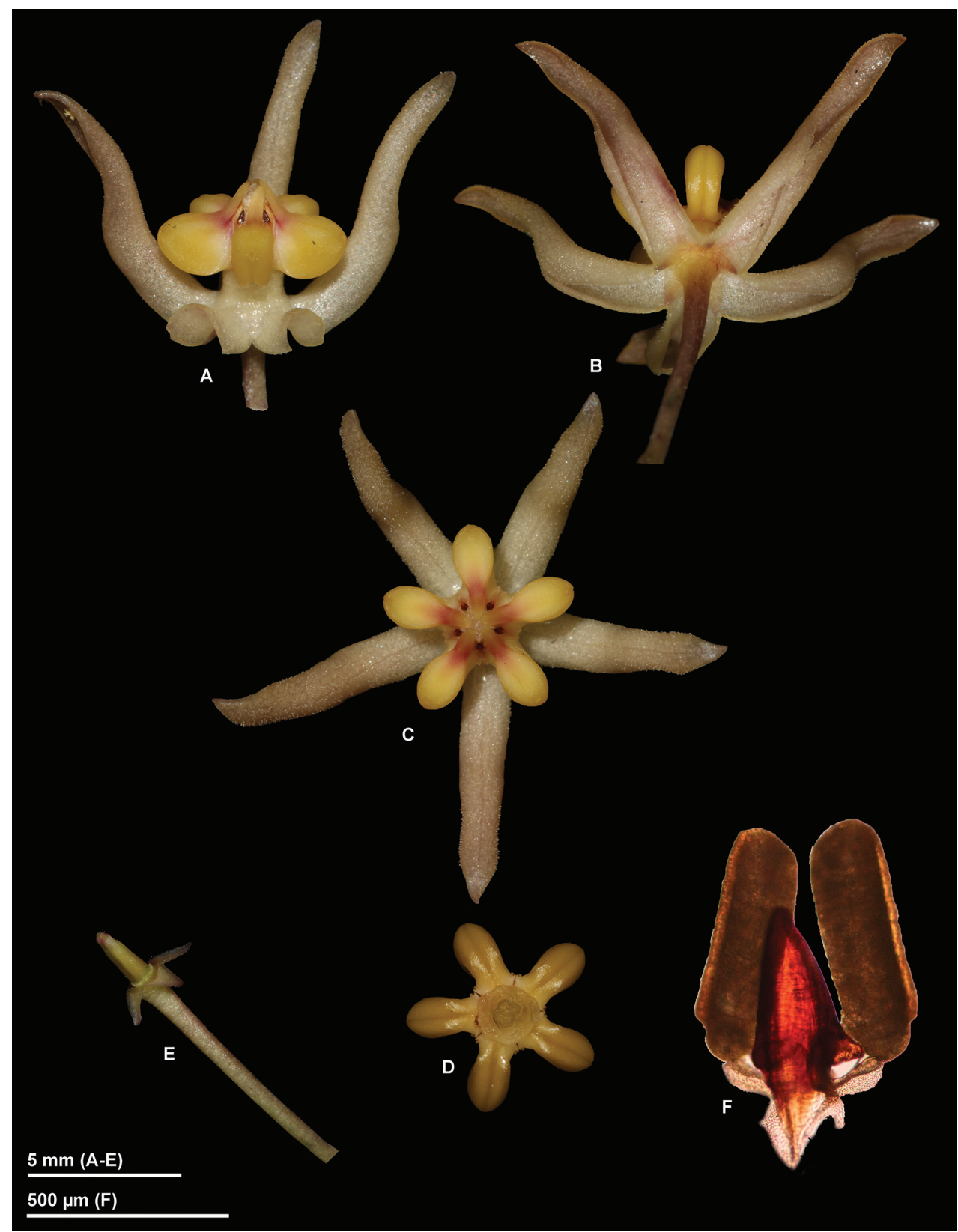

Figure I. Hoya ruthiae photographed from Rodda M. MR606 (SING) prior to pressing A Flower, lateral view with two corolla lobes removed $\mathbf{B}$ Corolla, underneath C Corolla and corona, top view D Corona, underneath E Pedicel, calyx and ovaries F Pollinarium with twin pollinia. (Photographs by M. Rodda)

lanceolate with a triangular acuminate apex, 9-10 $\times 3-4 \mathrm{~mm}$, laterally revolute, lobe tips recurved. Gynostegium stalked, corona column conical 1-1.2 × ca. $2 \mathrm{~mm}$ diam, glabrous; corona staminal, 2.5-3 $\mathrm{mm}$ high, 6-7 $\mathrm{mm}$ in diameter, fleshy, yellow with a purple 

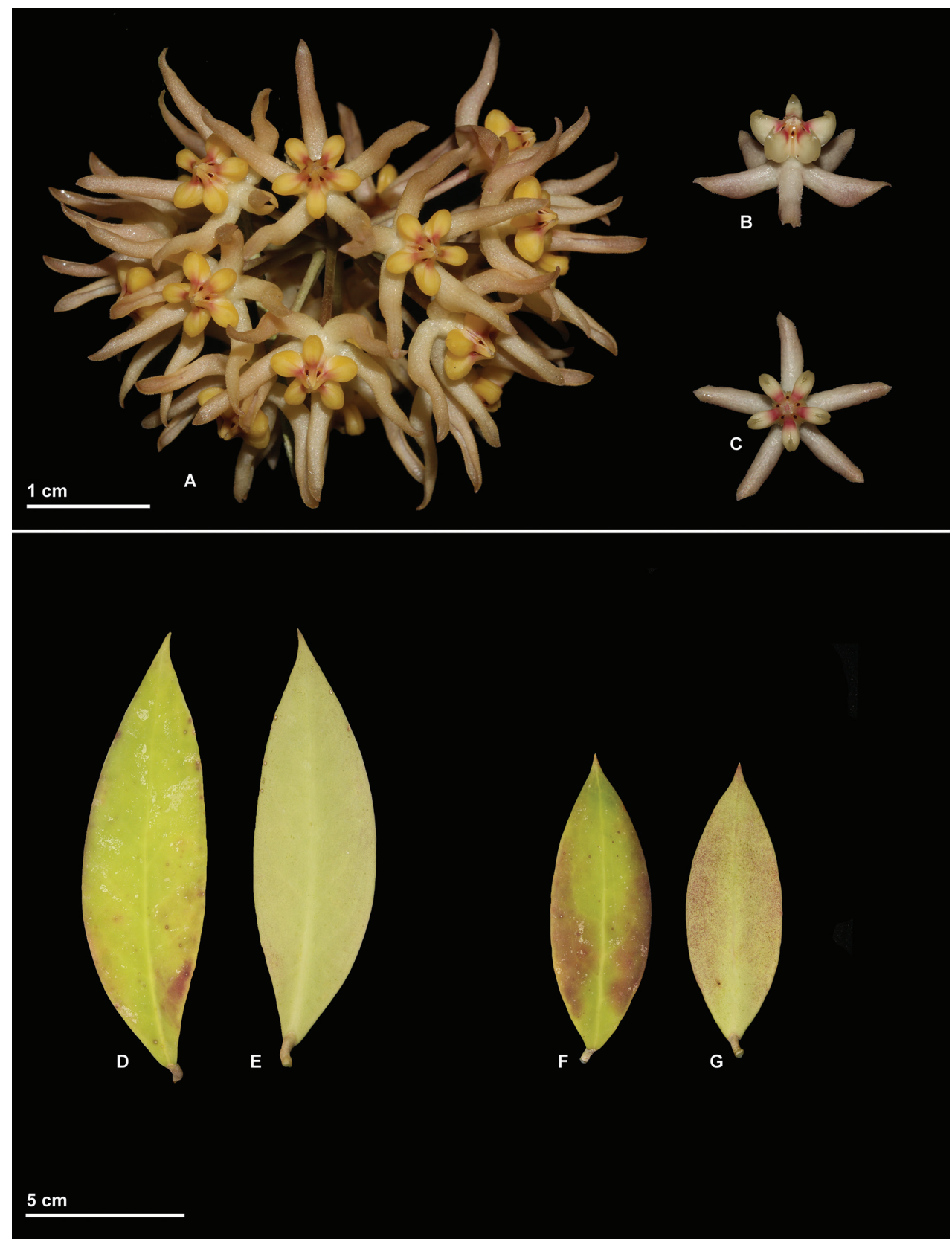

Figure 2. Hoya ruthiae photographed from Rodda M. MR606 (SING) prior to pressing A Inflorescence D, E, F, G Two leaves (D, F adaxial surface E, G abaxial surface). Hoya uncinata photographed from Rodda M MR607 (SING) prior to pressing B Flower, lateral view C Flower, top view. (Photographs by M. Rodda) 
centre; corona lobes laterally compressed, ovate above, with revolute margins beneath, 2.8-3.2 $\mathrm{mm} \times 1-1.2 \mathrm{~mm}$, inner process erecto-patent, linear with an acute tip, as high as the anthers, outer process round. Anthers ovate, 650-750 $\times 300-400 \mu \mathrm{m}$, with apical round membranaceous appendage as high as the style-head apex. Pollinia oblong, with obliquely truncate apex and round base and evident pellucid margin, 550-630 x 150-200 $\mu \mathrm{m}$; caudicles attached at the base of the retinaculum, elongate, ca. $150 \mu \mathrm{m}$ long, corpusculum 600-650 × 250-300 $\mu \mathrm{m}$; style-head 5-angled in cross section, with 5 spreading lobes alternating with the stamens; style-head apex columnar, 1-1.2 mm long, ca. $0.5 \mathrm{~mm}$ broad at the base, apex conical; ovary linear, ca. $2 \mathrm{~mm}$ long, each carpel ca. $0.5 \mathrm{~mm}$ wide at the base. Fruits and seeds unknown.

Etymology. This species is named after Ruth Kiew (1946-), tropical botanist based at the Forest Research Institute Malaysia and author of numerous publications on Begonia L. and Gesneriaceae, among others.

Distribution and ecology. Hoya ruthiae is only known from Bukit Baturong, Sabah, Malaysia, where it was found growing on limestone.

Conservation status. The distribution area, population size and possible threats to the habitat of $H$. ruthiae are not known, as it is only known from the type specimen and unlocalised cultivated material. It is therefore considered Data Deficient (DD) (IUCN 2014).

Notes. The most striking feature of $H$. ruthiae is its lack of coloured latex. Other species lacking coloured latex are the type species of the genus Hoya carnosa R.Br. and several morphologically similar taxa (Rodda and Simonsson Juhonewe 2012). All these have rotate corollas with thickly pubescent lobes within and rhomboid corona lobes with narrow inner and outer corona lobe processes. In Borneo only Hoya monetteae T. Green belongs to this group. Hoya ruthiae, as mentioned above, is morphologically very similar to Hoya uncinata, another non-laticiferous species known to occur in Java and Sumatra. Both species have deeply lobed rotate corollas, laterally compressed corona lobes and corpusculum of the pollinarium almost as large as the pollinium. Hoya ruthiae has larger flowers $(1.8-2.2 \mathrm{~cm}$ in diameter when flattened vs. $1.5-1.7 \mathrm{~cm})$ and the corolla lobes are narrowly lanceolate (vs. ovate in $H$. uncinata). The corona lobes of both species are ovate but in $H$. ruthiae the outer process is round while in $H$. uncinata it terminates in an incurved membranaceous apiculate appendage. Flowers of $H$. uncinata are illustrated in Fig. 2.

Additional specimens examined. Unlocalised (nursery origin), Cultivated in Thailand, Ratchaburi Prov., Ratchaburi, 23 March 2014, Rodda M MR606 (SING).

\section{Hoya bakoensis Rodda, sp. nov.}

urn:Isid:ipni.org:names:77148381-1

Figs 3-5

Diagnostic characters. Similar to Hoya aeschynanthoides Schltr. as both species have bilobed outer corona lobes, but differing in the size and colour of the flowers (3.5-4 
$\mathrm{mm}$ in diameter, pink corolla, yellow and red corona lobes for $H$. bakoensis; ca. $5 \mathrm{~mm}$ in diameter and white for $H$. aeschynanthoides) and in the habit, that in $H$. aeschynanthoides is decumbent while $H$. bakoensis is a weak twining climber.

Type. Malaysia, Borneo, Sarawak, Bako National Park, along Tajor Trail, 20 March 2015, Rodda M MR1042b (SING, holotype; SAR, KEP, isotypes)

Description. Epiphytic climber with white exudate in all vegetative parts. Stems slender, weakly twining upward, internodes $(1 \mathrm{~mm}-) 2-7(-10) \mathrm{cm} \times 0.7-1.5(-2) \mathrm{mm}$, dull green, sparsely pubescent when young, scabrous; adventitious root sparsely produced along the stems and just under the nodes where they are paired. Leaves petiolate; petiole straight or recurved, 4-10 $\times 1-1.5 \mathrm{~mm}$, dark green to maroon, sparsely pubescent; lamina ovate (lanceolate) $(1.5-) 2-4(-5) \times 1-2.8 \mathrm{~cm}$, base attenuate (acute), apex apiculate (cuspidate), dark green above, slightly pubescent on young leaves only, lighter green underneath with occasionally a slightly darker midrib and edge, glabrous, margin occasionally ciliate; penninerved, secondary veins obscure; colleters one at each lamina base, triangular to ovate $0.1-0.3 \times 0.3-0.5 \mathrm{~mm}$. Inflorescence pseudo-umbelliform, slightly convex, 10-15 flowered; peduncle 4-6 cm $\times 1-1.5 \mathrm{~mm}$ in diameter, dull green to brown, pubescent; rachis indeterminate $(-7) \times$ ca. $2 \mathrm{~mm}$ in diameter. Pedicel $3-7 \times 0.7-0.9 \mathrm{~mm}$ in diameter, pale green with pink spots, papillose. Calyx lobes triangular, $0.7-1 \times 0.5-0.8$ $\mathrm{mm}$, apex acute or round, light green with pink edge, sparsely ciliate; basal colleter one in each calyx lobe sinus, ovate, $150-200 \times 80-100 \mu \mathrm{m}$. Corolla revolute, $3.5-4 \mathrm{~mm}$ in diameter, ca. $6 \mathrm{~mm}$ when flattened; corolla lobes basally fused, tube $1.2-1.5 \mathrm{~mm}$ long, lobes triangular, 2-3 $\times 2.4-2.7 \mathrm{~mm}$, pink, pubescent inside, outside glabrous. Corona staminal, $2.8-3 \mathrm{~mm}$ in diameter, $0.9-1.1 \mathrm{~mm}$ high; corona lobes oblong, $1.2-1.4 \times 0.7-$ $0.8 \mathrm{~mm}$, convex above, underneath sulcate with inrolled margins, outer process apex bifid, light yellow, inner process elongate, red, with a yellow round tip. Anthers broadly triangular, 400-450 × 550-650 $\mu \mathrm{m}$, with apical triangular membranaceous appendage. Pollinia clavate, $200-250 \times 90-110 \mu \mathrm{m}$, narrowing towards the base, apex obliquely truncate, with evident pellucid margin; corpusculum oblong, constricted in the middle, 80-100 × 50-60 $\mu \mathrm{m}$; caudicle broad, spathulate, hyaline, $110-130 \times 30-45 \mu \mathrm{m}$ at the widest. Style-head 5 angled in cross section, with 5 lobes alternating with the stamens, style-head apex round, 200-300 $\mu \mathrm{m}$ long, ca. $0.5 \mathrm{~mm}$ broad at the base; ovary ovate with a narrow tip, $0.8-1 \mathrm{~mm}$, each carpel ca. $0.3 \mathrm{~mm}$ wide at the base, light green. Fruit (unripe) a single linear follicle, $10 \mathrm{~cm} \times 2 \mathrm{~mm}$ (widest), seed (unripe) narrowly lanceolate, 3-4 mm long, winged, long comose.

Etymology. The species is named after the collection locality of the holotype, Bako National Park (Sarawak, Malaysia).

Distribution and ecology. Hoya bakoensis is only known from Bako National Park, where it is common along Tajor Trail in moist, shady kerangas heath forest near a stream. The species is strictly epiphytic and it was found mostly germinating from the opening of small ant nests located inside hollow tree trunks (Fig. 4). The plants observed were forming small clumps of weakly climbing stems near the germinating point or more rarely were climbing towards the tree canopy potentially in response to low light. 


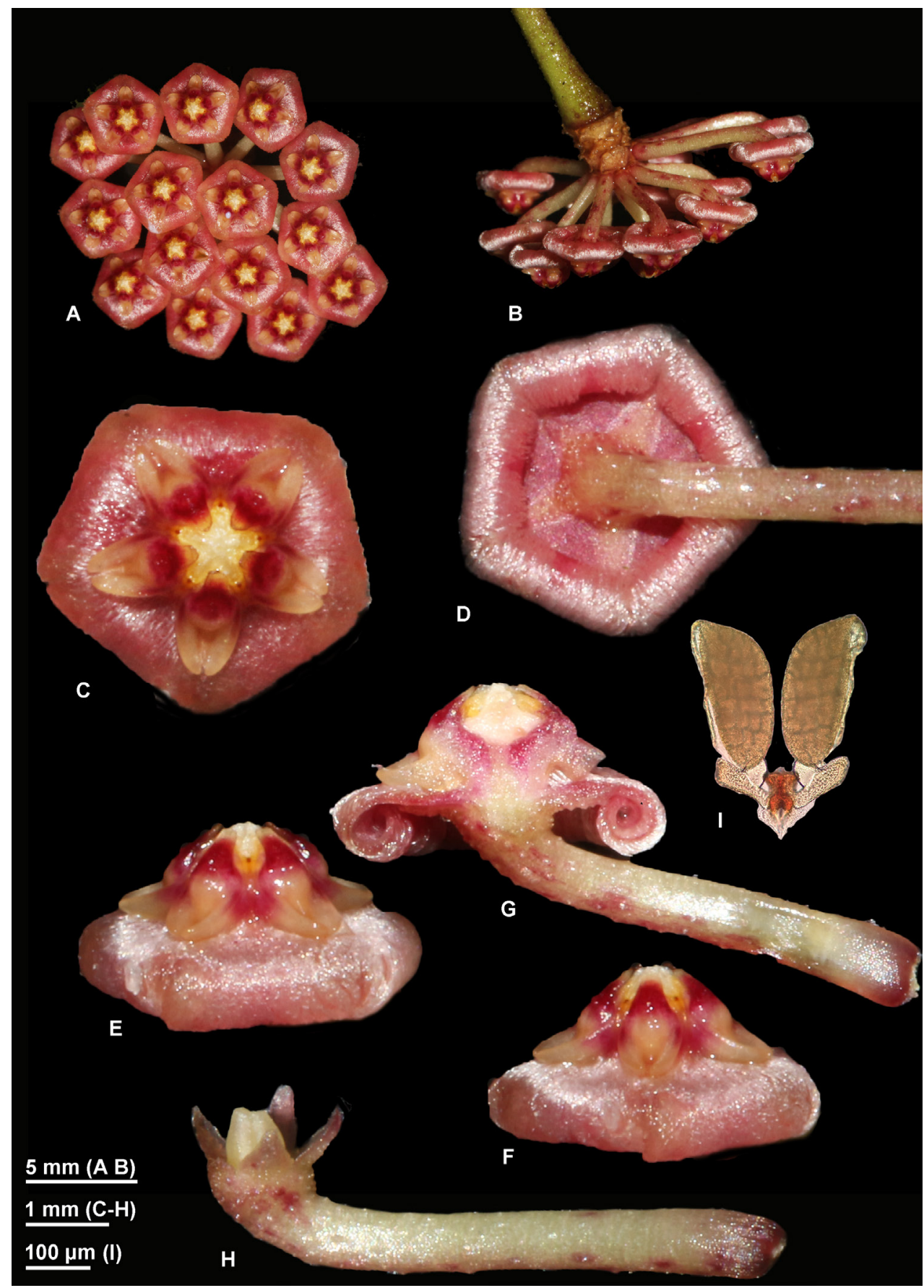

Figure 3. Hoya bakoensis photographed in the field from the type plant Rodda M MR1042b (SING) prior to pressing. A inflorescence, frontal view B Inflorescence, side view C A single flower, front view D Revolute margins of the corolla lobes, calyx and pedicel E, F Corolla, side view G Flower, longitudinal section H Pedicel, calyx and ovary I Pollinarium with twin pollinia. (Photographs by M. Rodda) 


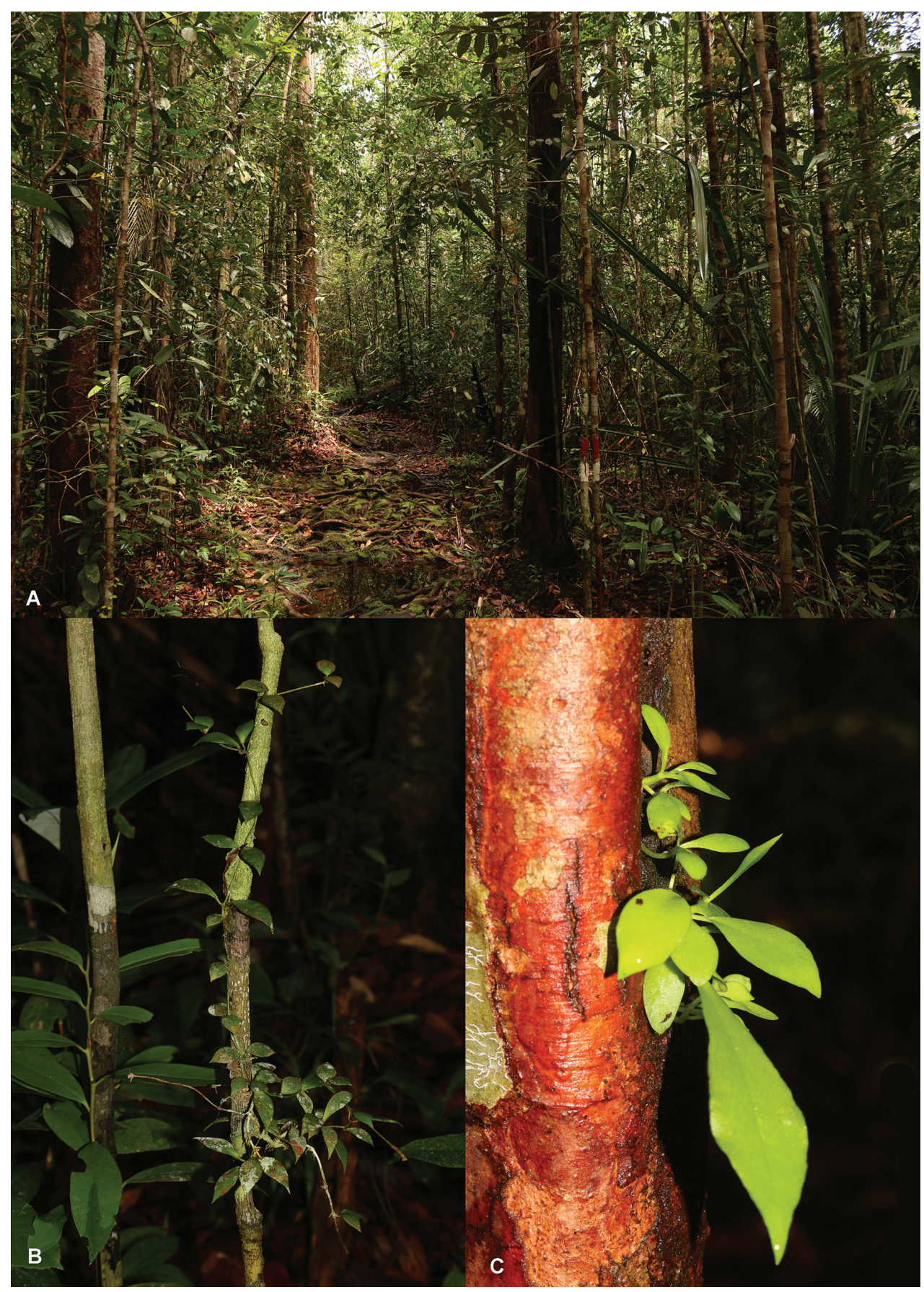

Figure 4. Hoya bakoensis in situ in Bako National Park (Sarawak, Malaysia) A Habitat, kerangas heath forest B Mature plant rooted inside the trunk of the host plant where an ant nest is located $\mathbf{C}$ Seedlings germinating from the opening of an ant nest in a hollow trunk. 


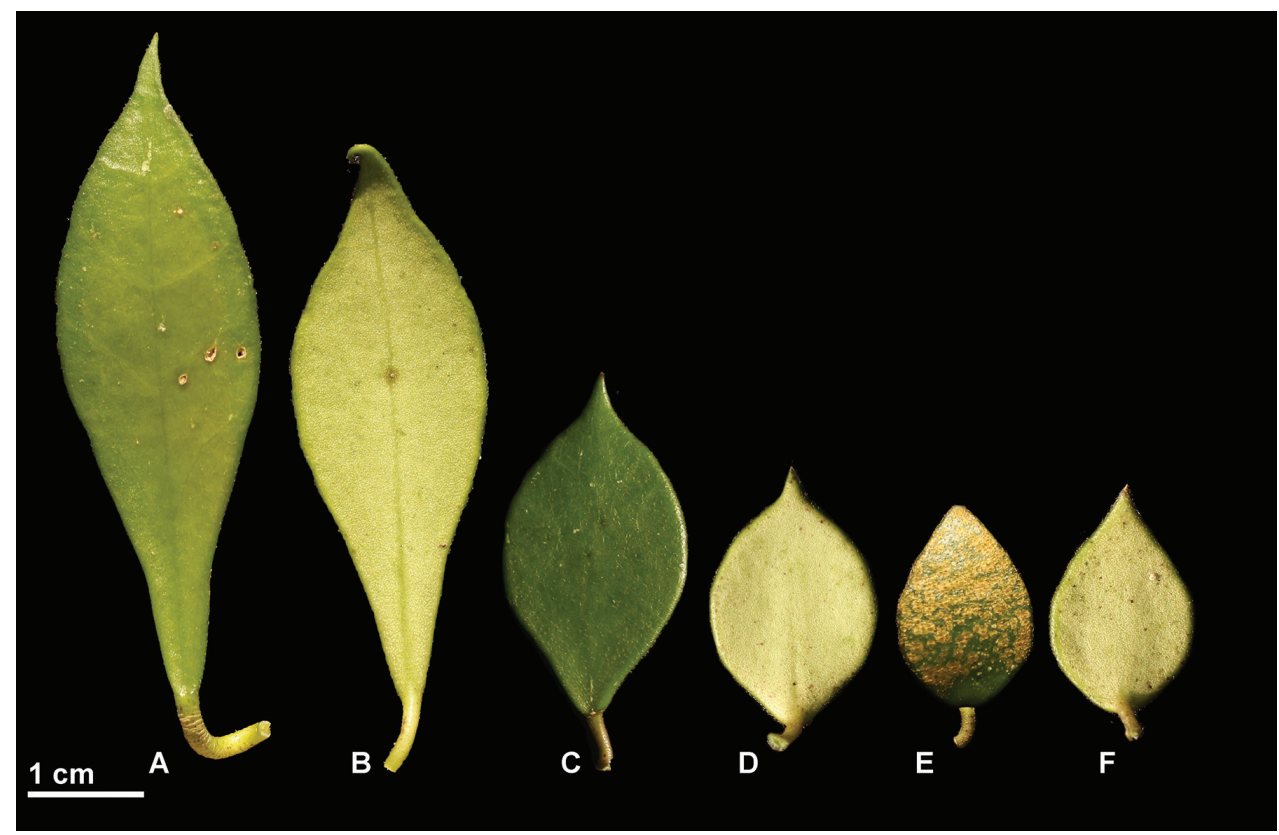

Figure 5. Hoya bakoensis leaves photographed in the field from Rodda $M M R 1042 b$ (A, B, E, F) and Rodda MMR1042a (C, D) (SING) prior to pressing. A, C, E Adaxial side B, D, F Abaxial side.

Conservation status. Hoya bakoensis is locally common and well protected inside Bako National Park. Its conservation status is therefore Least Concern (LC) (IUCN 2014).

Notes. Hoya bakoensis is one of the 11 Bornean Hoya species in Hoya section Acanthostemma (Bl.) Kloppenb. Acanthostemma species are characterised by revolute corolla lobes, bilobed outer corona lobes and pollinaria with broad, spathulate caudicles. The other Bornean species in Acanthostemma are H. aeschynanthoides, Hoya acicularis, T. Green, Hoya beccarii Rodda \& Simonsson, Hoya kloppenburgii T. Green, Hoya minutiflora Rodda and Simonsson, Hoya pubera Bl., Hoya revoluta Wight ex Hook.f., Hoya rundumensis (T. Green) Rodda and Simonsson, Hoya sigillatis T. Green and Hoya waymaniae Kloppenb.

Most of these species can be easily separated from $H$. bakoensis because their flowers are larger (>5 mm in diameter) or their inflorescence is markedly concave (in $H$. beccarii and $H$. revoluta). As mentioned in the diagnosis $H$. aeschynanthoides has white, only slightly larger flowers than $H$. bakoensis (ca. 5 vs. 3.5-4 mm in diameter). Additionally the bilobed outer lobes of $H$. aeschynanthoides appear to be less pronounced than those of $H$. bakoensis, but this observation is based solely on the examination of the drawing attached to the type of $H$. aeschynanthoides as only small buds are present on the specimen while no other specimens have been found at present. The flowers of $H$. pubera are also comparable in size with those of $H$. bakoensis, but they are yelloworange, the corolla lobes are only apically revolute and the corona is more markedly 
raised in the centre. Lastly, $H$. minutiflora has the smallest flowers among all Bornean Acanthostemma (2.6-2.8 $\mathrm{mm}$ in diameter).

Additional specimens examined. Malaysia, Borneo, Sarawak, Bako National Park, along Tajor Trail, 20 March 2015, Rodda M MR1042a (KEP, SAR, SING)

\section{Acknowledgements}

The National Parks Board Singapore is thanked for supporting this research by sponsoring field expeditions to Borneo and to numerous herbaria. I would like to thank the curators of BM, BRUN, FI, G, K, KEP, L, LAE, P, SAN, SAR, SNP, and SING herbaria for allowing access and/or for providing high quality images of herbarium specimens, the Forest Department Sarawak for allowing this research under permit NCCD.907.4.4(JLD.10)-205, the Park Managers and Wardens and all Park Staff for their support during fieldwork in Sarawak, Hee Yeong Leo for the English revision, and Ulrich Meve for his revision of the text.

Lastly I am grateful to Papaschon Chamwong for donating a specimen of Hoya ruthiae to the Singapore Botanic Gardens.

\section{References}

Green T, Kloppenburg RD (2014) New species of Hoya (Apocynaceae-Asclepiadoideae) from Sabah, Malaysia Hoya ranauensis, sp. n. Hoya New 2(3): 21-25. http://www.rare-hoyas. com/hoya_2-3.pdf

The International Plant Name Index (2015) Published on the Internet. http://www.ipni.org [accessed 10 March 2015]

IUCN Standards and Petitions Subcommittee (2014) Guidelines for using the IUCN Red List categories and criteria. Version 11. Prepared by the Standards and Petitions Subcommittee. Downloadable from http://www.iucnredlist.org/documents/RedListGuidelines.pdf

Kleijn D, Van Donkelaar R (2001) Notes on the taxonomy and ecology of the genus Hoya (Asclepiadaceae) in Central Sulawesi. Blumea 46: 457-483.

Lamb A, Gavrus A, Emoi B, Gokusing L (2014) The Hoyas of Sabah, a commentary with seven new species and a new subspecies. Sandakania 19: 1-89.

Nutt P (2001) Checkliste der Gattung Hoya auf Borneo (Apocynaceae-Asclepiadoideae). Diploma thesis, Westf. Wilhelms-Universitaet Münster, 122 pp.

Rodda M (2014) Hoya (Apocynaceae-Asclepiadoideae) of Brunei Darussalam. Princess Rashidah Young Nature Scientist Award 16: ix-xii.

Rodda M, Nyhuus T (2009) Hoya danumensis, a new species of Hoya (Apocynaceae, Asclepiadoideae) from Borneo. Webbia 64: 163-167. doi: 10.1080/00837792.2009.10670856

Rodda M, Simonsson N (2010) Hoya minutiflora sp. nov. (Apocynaceae, Asclepiadoideae) a new small-flowered Hoya species, and taxonomic notes on Hoya ruscifolia Decaisne. Webbia 65: 173-178. doi: 10.1080/00837792.2010.10670872 
Rodda M, Simonsson N (2011a) Hoya devogelii (Apocynaceae Asclepiadoideae), a new species from kerangas heath forests in Sarawak, Borneo. Webbia 66: 33-38. doi: 10.1080/00837792.2011.10670882

Rodda M, Simonsson N (2011b) Hoya medinillifolia (Apocynaceae Asclepiadoideae), a new species from lowland forests of Sarawak, Borneo. Webbia 66: 149-154. doi: 10.1080/00837792.2011.10670893

Rodda M, Simonsson Juhonewee N (2012) Hoya vangviengiensis (Apocynaceae, Asclepiadoideae), a new species from limestone formations of Vang Vieng, Lao PDR. Webbia 67: 23-27. doi: 10.1080/00837792.2012.10670904

Rodda M, Simonsson Juhonewee N (2013a) The taxonomy of Hoya micrantha and Hoya revoluta (Apocynaceae, Asclepiadoideae). Webbia 68: 7-16. doi: 10.1080/00837792.2013.802937

Rodda M, Simonsson Juhonewee N (2013b) Hoya nuttiana (Apocynaceae, Asclepiadoideae), a new species from Sarawak, Malaysian Borneo. Phytotaxa 140: 56-60. doi: 10.11646/ phytotaxa.140.1.6

Rodda M, Simonsson N, Wanntorp L (2011) Hoya wongii (Apocynaceae, Asclepiadoideae): a new campanulate flowered species from Brunei (Borneo). Blumea 56: 205-208. doi: $10.3767 / 000651911 \times 594423$

Rodda M, Ercole E, Simonsson Juhonewe N (2014a) Hoya corymbosa (Apocynaceae, Asclepiadoideae), a new unusual species from Sabah, Borneo, and its systematic position based on phylogenetic analysis. Systematic Botany 38: 1125-1131. doi: 10.1600/036364413X674733

Rodda M, Simonsson Juhonewe N, Sri Rahayu (2014b) Taxonomic revision of the Hoya mindorensis complex (Apocynaceae:-Asclepiadoideae). Webbia 69: 39-47. http://www.tandfonline.com/doi/abs/10.1080/00837792.2014.900261

Trân TB, Kim JH, Kim DK, Lee J, Bui TH, Simonsson N, Rodda M (2011) Hoya ignorata (Apocynaceae, Asclepiadoideae): an overlooked species widely distributed across South East Asia. Novon 21: 508-514. doi: 10.3417/2010068 